\title{
Efficacy of Legumes Conservation by the Introduction of Lactobacillus RS4 from Epiphytic Microflora of Clover
}

\author{
Ravilya A. Shurkhno (Corresponding author) \\ JSC Tatarstan Scientific and Production Association BioAgro \\ Cheluskin str., 28, Kazan, 420127, Russia \\ E-mail: Ravillya@yandex.ru
}

\begin{abstract}
Alexey I. Kolpakov
Kazan (Volga-Region) Federal University, Kremlevskaya str., 18, Kazan, 420008, Russia

E-mail: ljoscha@mail.ru
\end{abstract}

Fafziya S. Gibadullina

Tatar Institute of Agriculture, Russian Academy of Agricultural Sciences

Orenburskii tr., 48, Kazan, 420059, Russia

E-mail: tatniva@mail.ru

Olga N. Ilinskaya

Kazan (Volga-Region) Federal University

Kremlevskaya str., 18, Kazan, 420008, Russia

E-mail: ilinskaya_kfu@mail.ru

Received: July 10, 2014 Accepted: July 25, 2014

doi:10.5296/jas.v2i2.5946 URL: http://dx.doi.org/10.5296/jas.v2i2.5946

\section{Abstract}

Biological preservative on the basis of native strain of lactic acid bacterium Lactobacillus RS4, 
isolated from epiphytic microflora of clover, is recommended for practical application by preparation of forages from the high-protein dried crops. The comparative analysis of chemical composition, organic acids, amino acids and nutritional value of the main forage crops, and also characteristic parameters of three options of silages of clover revealed that the introduction of lactobacilli in plant biomass is economically effective.

Keywords: Lactic acid bacteria, Silage, Clover, galega, Alfalfa, Organic acid, Amino acids, Ferment.

\section{Introduction}

Lactic acid bacteria (LAB) make up a heterogeneous group of bacteria that is met meet in various ecological niches, including those of the intestinal microflora of the humans and mammals, as well as and epiphytic and rhizosphere communities of plants (Van de Guchte et al., 2002). In the rhizosphere of plants, the LAB are at a higher quantity than in epiphytic microflora. It is believed that the group of these microorganisms in the course of evolution was deeply interconnected with a plant (Kvasnikov et al., 1975).

In this regard, lactobacilli from natural sources are considered as perspective preservatives of plant materials (Dellaglio et al., 1986). About positive results of application of LAB at conservation of forages, which are especially hard to ensile, report a great number of authors (Oshima et al., 1978; Kvasnikov et al., 1975; Oshima et al., 1979; McDonald, 1985; Cussen et al., 1995; Woolford et al., 1984; Driehuis et al., 2000; Acosta Aragon et al, 2012).

Plant protein is known as the cheapest; its application for compensation of protein deficiency in diets of animals is one of the main and effective directions in preparation of forages. The crucial role belongs to leguminous species as sources of vegetable protein where the protein content is 1.5-3-fold more than in cereals (Zherukov et al., 2003). Protein of fodder herbs contains full set on amino acids including a significant amount of essential ones. Besides, leguminous crops can grow without fertilizers partly because of nitrogen fixation by the symbiotic forms of rhizosphere microorganisms and therefore are treated as sources of ecologically safe proteins.

As leguminous species possess high fodder value, the search for technologies of safety of nutrients of these cultures and quality of the forage received after conservation represents extremely actual task.

The goal of this work was the analysis of introduction efficiency of an epiphytic strain of Lactobacillus RS4 in scaled-up production of the ensiling process of clover biomass and the characterization of conservation product quality.

\section{Research Methods}

\subsection{Samples}

Leguminous plants grasses: the experiment used a red clover (Trifolium pratense L.) cultivar Early-2, galega east (Galega orientales L.) cultivar to Gale, alfalfa changeable (Medicago varia Martyn) Ayslu's cultivar. 


\subsection{Inoculant}

Lactobacillus RS4 was isolated from a phyllosphere of red clover (Shurkhno et al., 2005). The strain was registered in microbial collections of Tatar Research Institute of Agriculture (Russian Academy of Agricultural Sciences) and of Institute of Biochemistry and Physiology of Microorganisms (Russian Academy of Sciences); the registration number appropriated by All-Russia Collection Microorganisms is All-RCM V-2343 D. The strain was also patented (No. 2309605 of 10.11.2007) (Shurkhno et al., 2007).

\subsection{Fermentation of Plant Mass}

Determination of nutritiousness and safety of the received forage was carried out under the conditions of scaled-up production. For this purpose the crushed mass of a red clover collected in the phase of initial flowering was dried to $39-40 \%$ content of dry substance (Petukhova et al., 1989). The partially dried material was inoculated with a 1-day culture of the $L$. RS4. Inoculation was aseptic and involved distribution of $10 \mathrm{ml}$ of cell suspension (titre: $10^{6}$ colony-forming units $(\mathrm{CFU}) / \mathrm{ml})$ throughout $1 \mathrm{~kg}$ of the plant mass; also a variant with treacle addition $(40 \mathrm{~g} / \mathrm{kg})$ was used. The plant material to be ensiled was placed into sterile polyethylene bags, stamped and tightly closed for the creation of adverse conditions for obligatory and facultative aerobic microorganisms. All experiments were made in triplicate. Ready-made feeds were opened after 60 days.

\subsection{Chemical Methods}

Samples of silage $(5 \mathrm{~g}$ ) were homogenized in $10 \mathrm{ml}$ deionised water, after filtration (Gerhard, 1984) in liquid phase $\mathrm{pH}$ was measured (pH-Meter Toledo MP-120, Germany). Fermentation products were analysed using Perkin Elmer Series 200 (USA) HPLC chromatograph equipped with a column $\mathrm{C} 18(250 \times 4.6 \mathrm{~mm})$ and a refractive index detector. $\mathrm{H}_{3} \mathrm{PO}_{4}(0.1 \%)$ was used for elution. Eluent flow rate was $0.6 \mathrm{ml} / \mathrm{min}$; temperature, $30^{\circ} \mathrm{C}$. Water solutions of organic acids, produced by ACROS (Belgium), were used as standards. The samples were prepared using SerPak C-18 cartridges (TESSEK, Czech Republic) filled with a Saparin of the SGX 1/218 (pore diameter of $60 \mu \mathrm{m}$, for removal of high-molecular-weight compounds and pigment substances).

Amino acidic composition of proteins was analysed using a Perkin Elmer Series 200 (USA) HPLC chromatograph equipped with a column C18 $(150 \times 2.1 \mathrm{~mm})$ and detector with a diode matrix of II. Average samples were dried, crushed, hydrolysed and filtrated. For hydrolysis, the samples were places into ampoules containing $\mathrm{Ba}(\mathrm{OH})_{2}$ for analysis of tryptophan, and $\mathrm{HCl}$ for other amino acids. The soldered ampoules were incubated during $24-48 \mathrm{~h}$ for acidic and $18 \mathrm{~h}$ for alkaline hydrolysis by $110^{\circ} \mathrm{C}$. The chromatography was carried out in gradient mode at consumption of eluent $1.5 \mathrm{ml} / \mathrm{min}$; temperature of column $30^{\circ} \mathrm{C}$. The mobile phase used was $2.5 \mathrm{mmol} \mathrm{KH}_{2} \mathrm{PO}_{4}(0.025 \mathrm{M}), \mathrm{pH} 7.0$ (component A), acetonitrile and methanol mix in the ratio 70:30 (component B) and water distilled (component C). Amino acids, produced by ACROS (Belgium), were used as standards. 


\subsection{Physical and Chemical Indicators}

Dry matter was determined in plant mass and samples of silage by drying at $105^{\circ} \mathrm{C}$ (GOST 27548).

Assessment of nutritiousness according to the maintenance of exchange energy was carried out on the basis of the digested nutrients given about the contents (Petukhova et al., 1989).

Total nitrogen was assayed by the Kjeldahl method by burning organic substances in concentrated $\mathrm{H}_{2} \mathrm{SO}_{4}$, resulting ammonium was measured by a titrimetric method. The analysis was carried out in an automatic mode (VELP Scientifica, Italy), which consisted of a digester for a wet combustion (DK-6) and the full automatic distillation device with the built-in titrator (UDK-152). The content of nitrogen in a studied material, with the subsequent recalculation on the total nitrogen, was estimated in accordance with GOST 13496.4.

Total fat was assayed in an automatic regime (SER 148, VELP Scientifica, Italy), based on the hot extraction of crude fat from samples by diethyl ether (GOST 13496.15).

Crude fibre was assayed in an automatic mode (FIWE 6, VELP Scientifica, Italy). The method is based on the removal from sample of all substances which can be dissolved in acid and alkaline, followed by the determination of resting weight of non-soluble fibre (GOST 13496.2).

Sugars were assayed by extraction of soluble carbohydrates from plant mass and silage samples with distilled water at $50-60^{\circ} \mathrm{C}$, and subsequent extraction of the rest with $1 \% \mathrm{H}_{2} \mathrm{SO}_{4}$ for easily hydrolyzed carbohydrates like starch (GOST 26176). Optical density at $610 \mathrm{~nm}$ was analysed using Perkin Elmer Lambda 35 (USA).

Calcium was determined by burning of sample in hydrochloric acid followed by sedimentation of calcium in the form of calcium oxalate. The sediment was dissolved in $\mathrm{H}_{2} \mathrm{SO}_{4}$ and titrated with permanganate of potassium. Definition of calcium content was carried out according to GOST 26570.

The content of phosphorus was estimated by its mineralization in concentrated $\mathrm{H}_{2} \mathrm{SO}_{4}$ in the presence of $\mathrm{H}_{2} \mathrm{O}_{2}$ and the subsequent measurement of density of the colored phosphorus-molybdenum complex using Perkin Elmer Lambda 35 (USA) (GOST 26657).

The content of carotene in the samples was determined by carotene dissolution in gasoline (nefras-S 50/170) and density measurement of the solution using Perkin Elmer Lambda 35 (USA) (GOST 13496.17).

\subsection{Date Analysis}

Statistical processing of results was carried out using the program Microsoft Office Excel 2013.

\section{Results and Discussion}

\subsection{Characteristic of Plant Materials}


We investigated the chemical composition and nutritiousness of green material of a red clover (Trifolium pratense) cultivar Early-2, a fodder galega (Galega orientalis) cultivar Gale, alfalfa changeable (Medicago varia Martyn) cultivar Ayslu. The dried biomass of the clover, which has been selected according to optimal indicators of nutrients content, was used for conservation. The scheme of experiment included control variant, variant with the addition of treacle $(40 \mathrm{~g} / \mathrm{kg})$, and also conservation with introduced homofermentative, osmotolerant Lactobacillus RS4 strain $(0.07 \mathrm{ml} / \mathrm{kg})$.

Nutritional value and chemical components of green mass of leguminous crops are presented in Table 1.

Table 1. Components of green mass of perennial leguminous herbs grown under natural conditions*

\begin{tabular}{|l|c|c|c|}
\hline \multirow{2}{*}{ Components } & \multicolumn{3}{c|}{ Species } \\
\cline { 2 - 4 } & Red clover & Fodder galega & Alfalfa changeable \\
\hline Dry matter, g/kg & 220 & 237 & 252 \\
\hline Metabolic energy, MJ/kg (calculated) & 2.14 & 2.32 & 2.30 \\
\hline Crude protein, g/kg & 43.9 & 54.7 & 53.2 \\
\hline Crude fat, g/kg & 8.0 & 6.9 & 9.8 \\
\hline Crude fiber, g/kg & 61.1 & 69.9 & 69.2 \\
\hline Water soluble carbohydrates, g/kg & 14.2 & 10.2 & 9.1 \\
\hline Calcium, g/kg & 4.5 & 4.8 & 5.2 \\
\hline Phosphorus, g/kg & 0.7 & 0.9 & 0.8 \\
\hline Carotene, $\mathrm{mg} / \mathrm{kg}$ & 44.7 & 53.7 & 39.2 \\
\hline
\end{tabular}

*Mean square deviation of triplicate data $6 \leq 12 \%$.

The studied leguminous crops possess high nutritional value in the form of green mass as well as in the form of forages like silage and hay. We estimated the structure and nutritional value of green mass in the phase of the beginning of flowering. The level of moisture in biomass of studied plants was comparable; it varied ranging from $74.8 \%$ to $78 \%$. The comparative analysis of key parameters showed that the crude protein content was very high in green mass of galega $(54.7 \mathrm{~g} / \mathrm{kg})$ and alfalfa $(53.2 \mathrm{~g} / \mathrm{kg})$ in comparison with clover $(43.9 \mathrm{~g} / \mathrm{kg})$.

The maximum quantity of crude fat among analysed herbs was found in alfalfa $(9.8 \mathrm{~g} / \mathrm{kg})$ whereas the galega has less than $2.9 \mathrm{~g} / \mathrm{kg}$ and clover less than $1.8 \mathrm{~g} / \mathrm{kg}$ of fat. Values of crude fibre are comparable for all studied species, for alfalfa $(69.2 \mathrm{~g} / \mathrm{kg})$, galega $(69.9 \mathrm{~g} / \mathrm{kg})$ and clover $(61.1 \mathrm{~g} / \mathrm{kg})$. Concentration of soluble carbohydrates in green mass of clover was about $28 \%$ and $36 \%$ more than in galega and alfalfa, respectively that corresponds to earlier obtained data (Shurkhno et al., 2006).

No difference in the phosphorus content between species of leguminous crops was found $(0.7-0.9 \mathrm{~g} / \mathrm{kg})$. The maximum quantity of calcium was revealed in alfalfa $(5.2 \mathrm{~g} / \mathrm{kg})$, whereas in clover its content was $4.5 \mathrm{~g} / \mathrm{kg}$, and in galega $4.8 \mathrm{~g} / \mathrm{kg}$. Among carotenoids, carotene possesses the greatest activity, and it collects in green plants up to the maximum quantity prior of the flowering phase.

The preservation of carotene at conservation of green forages is higher, than by drying 
(Zaripova et al., 2010). The greatest concentration of carotene was found in green mass of galega $(53.7 \mathrm{mg} / \mathrm{kg}$ ), whereas for clover this value was $44.7 \mathrm{mg} / \mathrm{kg}$ and for alfalfa $39.2 \mathrm{mg} / \mathrm{kg}$. Thus, all studied cultures possess high productive qualities, however for scaled-up production tests we selected the clover as it is capable in one year to realize the potential of nitrogen fixation (that is absent for grain crops) and the transformation of solar energy into organic substance; increases fertility of the soil and structures it; solves the problem of cost and protein deficit of forages (Shurkhno et al., 2001; Kosolapov et al., 2009; nadezhkin et al., 2006).

\subsection{PH and Content of Organic Acids}

When plant species with the high content of protein and rather low content of sugar are used, it is necessary to stimulate the development of lactic acid bacteria. In a series of experiments with clover, we added to clover a product of incomplete acidic or fermentative conversion of starch with high level of carbohydrates, the treacle, to increase the content of components available for growth of lactic acid bacteria, and to obtain advantages of the resulting forages.

Hihg acidity in the preserved mass is an integral indicator of good silage. In the course of drying, significant amounts of simple sugars formed, that facilitates acidulation of fodder mass. The analysis of obtained data showed (Figure 1A) that all samples were characterized by low $\mathrm{PH}$ values (4.3-4.4).
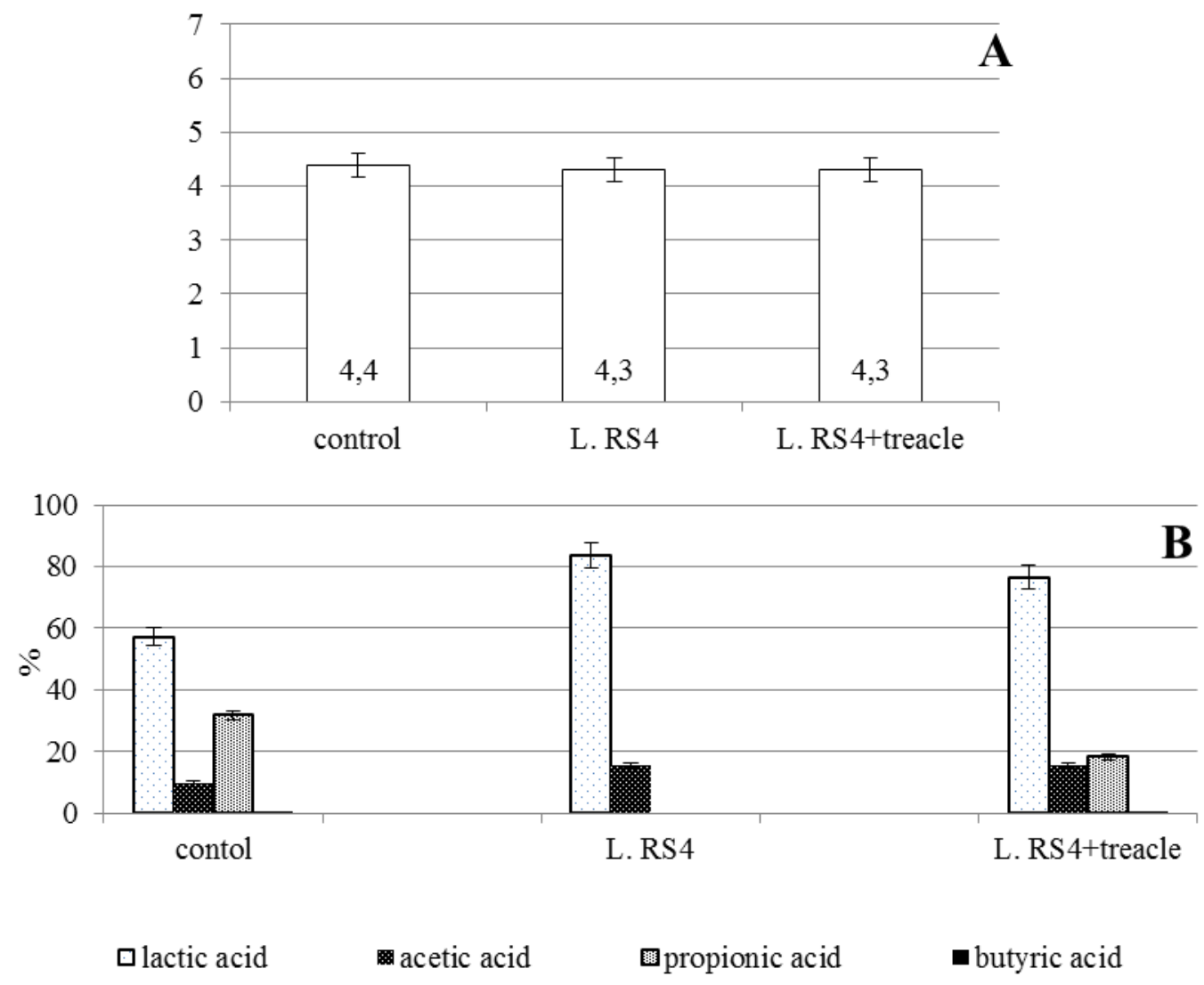

Figure 1. PH value (A) and content of organic acids (B) in clover silages. For $100 \%$ the total amount of identified acids was taken. 
Lactic acid is of great importance in the process of ensiling, as it possesses much higher constant of dissociation $(\mathrm{C}=0.0138)$, than acetic $(\mathrm{C}=0.0018)$ and some other acids. Its bactericide and fungicide action do not connected with appearance of resistant microflora, unlike action of antibiotics. Being natural metabolite, lactic acid completely assimilates in an organism of animal, bringing benefits in the form of additional energy and improving organoleptic indicators of conserved forage (Grigoriev et al., 1989).

The content of lactic acid was the highest in the variant of clover with $L$. RS4 (83.6\%) at PH 4.3. Three main organic acids were found in silage from clover without any additions: the ratio of lactic, acetic and propionic acid in control variant was 57.1: 9.9: 31.7\% (Figure 1B). This proportion in variant of silage with $L$. RS4 + treacle was 76.5: 0.50: $18.3 \%$. According to the present standard the level of undesirable butyric acid in silage can vary from $0.1 \%$ to $0.2 \%$ (GOST 23637, 1990). Usually, the content of butyric acid is in inverse dependence from the content of lactic acid. The higher speed of lactic fermentation in wet material compared with dry one, often promotes the decrease of butyric acid content in feed product: in variants with $L$. RS4 + treacle its content was $0.02 \%$, in control variant was $0.08 \%$ (Figure 1B).

\subsection{Amino Acid Composition of Proteins in Clover and Silage}

Degradation of protein is favoured under conditions of ensiling unripe species with high moisture content. A number of authors testify that in the silage prepared from fresh herbs more than $50 \%$ of protein are split, while in the silage prepared from the dried plant mass this amount is less than 30\% (Watson et al., 1964; Kvasnikov et al., 1975; McDonald, 1985; Cussen et al., 1995). Some ways of machining like plant breaking or crushing, increase the extent of protein degradation. At our experiments the ensiling process proceeded with limited proteolysis and preserved the main nutritious components of forage (Table 2).

The amino acid composition of proteins of clover green mass and of three forage samples is presented in Table 2. The sum of all amino acids in green herbs was $35.33 \mathrm{~g} / \mathrm{kg}$, the sum of essential amino acids was $16.13 \mathrm{~g} / \mathrm{kg}$; of the non-essential amino acids it was $19.20 \mathrm{~g} / \mathrm{kg}$. The calculated amino acid index was 0.84 . It specifies that the clover belongs to sterns with the high content of essential amino acids (Gibadullina, 2007).

\subsection{Chemical Analysis of Silages}

Amount of dry matter in silage from clover are comparable in all three variants: control (400 $\mathrm{g} / \mathrm{kg}$ ), with $L$. RS4 (388 g/kg), and variant with treacle (402 g/kg). At large-scale preparation of forages this indicator plays extremely important role in preservation of sugars - the main source of energy (Vyayzenen et al., 2010). The actual quantities of crude protein in variant with L. RS4 was $62.8 \mathrm{~g} / \mathrm{kg}$; with treacle, $62.7 \mathrm{~g} / \mathrm{kg}$; and control, $61 \mathrm{~g} / \mathrm{kg}$. The amino acid composition of proteins of all three variants of forage is presented in Table 2. The highest content was defined in silage with an introduction of $L$. RS4 $(51.50 \mathrm{~g} / \mathrm{kg})$ In variant with treacle and control variant the total content of amino acids was 50.95 and $46.31 \mathrm{~g} / \mathrm{kg}$, respectively. 
Table 2. Quantitative and qualitative composition of proteins in green mass of clover and it's silages under natural conditions $(\mathrm{g} / \mathrm{kg})^{*}$

\begin{tabular}{|c|c|c|c|c|c|}
\hline \multirow[t]{2}{*}{ № } & \multirow[t]{2}{*}{ Components } & \multirow{2}{*}{\begin{tabular}{|l} 
Green \\
mass
\end{tabular}} & \multicolumn{3}{|c|}{ Silages } \\
\hline & & & control & L. RS4 & L. $R S 4+$ treacle \\
\hline \multicolumn{6}{|c|}{ Chemical composition: } \\
\hline 1. & Dry matter & 220 & 400 & 388 & 402 \\
\hline 2. & Crude protein & 43.9 & 61.0 & 62.8 & 62.7 \\
\hline \multicolumn{6}{|c|}{ Amino acid composition: } \\
\hline 3. & Lysine & 2.20 & 2.40 & 2.60 & 2.50 \\
\hline 4. & Valine & 2.20 & 2.30 & 3.00 & 3.20 \\
\hline 5. & Leucine & 2.62 & 3.01 & 3.35 & 3.30 \\
\hline 6. & Threonine & 2.00 & 2.20 & 2.60 & 2.50 \\
\hline 7. & Histidine & 1.00 & 1.20 & 1.80 & 1.60 \\
\hline 8. & Methionine & 0.71 & 1.00 & 1.60 & 1.40 \\
\hline 9. & Tryptophan & 0.80 & 1.00 & 1.10 & 0.90 \\
\hline 10. & Isoleucine & 1.30 & 1.50 & 1.50 & 1.70 \\
\hline 11. & Phenylalanine & 1.80 & 1.60 & 2.10 & 2.10 \\
\hline 12. & Arginine & 1.50 & 1.60 & 1.85 & 1.65 \\
\hline 13. & Serine & 2.15 & 3.00 & 2.70 & 3.60 \\
\hline 14. & Alanine & 1.05 & 4.50 & 5.00 & 4.60 \\
\hline 15. & Glycine & 1.55 & 4.00 & 4.40 & 4.00 \\
\hline 16. & Cystine & 0.60 & 1.50 & 1.80 & 1.80 \\
\hline 17. & Aspartic acid & 8.80 & 7.00 & 7.50 & 7.10 \\
\hline 18. & Glutamic acid & 5.05 & 8.50 & 8.60 & 9.00 \\
\hline \multicolumn{2}{|c|}{ The sum of amino acid: } & 35.33 & 46.31 & 51.50 & 50.95 \\
\hline \multicolumn{2}{|c|}{ The sum of essential amino acids } & 16.13 & 17.81 & 21.50 & 20.85 \\
\hline \multicolumn{2}{|c|}{ The sum of non-essential amino acids } & 19.20 & 28.50 & 30.00 & 30.10 \\
\hline \multicolumn{2}{|c|}{ Amino acid index: } & 0.84 & 0.63 & 0.72 & 0.69 \\
\hline
\end{tabular}

* Mean square deviation of triplicate data $6 \leq 12 \%$.

Ratios of essential and non-essential amino acids were the following: in silage control sample, 17.81: $28.50 \mathrm{~g} / \mathrm{kg}$; with an introduction of $L$. RS4, 21.23: $30.0 \mathrm{~g} / \mathrm{kg}$; and with treacle, 20.85: $30.10 \mathrm{~g} / \mathrm{kg}$. The amino acid indexes were $0.63 ; 0.72$ and 0.69 , respectively. It is important to note that from total amount of amino acids the part of essential ones was $38.5 \%$ in control variant, $41.8 \%$ in variant with $L$. RS4, and $40.9 \%$ in variant with treacle that conforms to requirements of quality for valuable nutrients obtained in processes of their preparation and storage.

The analysis of chemical composition of clover silage is presented in Table 3.

All studied variants of silage compared on metabolic energy which corresponds to nutritional value of forages, show equal value $(3.8 \mathrm{MJ} / \mathrm{kg}$ ) for each one. According to protein content, variants with introduced $L$. RS4 and with treacle were equivalent: $62.8-62.7 \mathrm{~g} / \mathrm{kg}$, and in control, $61.0 \mathrm{~g} / \mathrm{kg}$. The amount of crude cellulose varied from 102.4 to $107.2 \mathrm{~g} / \mathrm{kg}$. Safety of soluble carbohydrates in variant with introduced $L$. RS4 was $12.6 \mathrm{~g} / \mathrm{kg}$, in control $12.0 \mathrm{~g} / \mathrm{kg}$; and with treacle $17.4 \mathrm{~g} / \mathrm{kg}$. Levels of important minerals in variants of silage were comparable for calcium $(6.6-6.9 \mathrm{~g} / \mathrm{kg}$ ) and phosphorus $(1.2-1.3 \mathrm{~g} / \mathrm{kg})$. The insignificant difference was observed in the content of carotene: with $L$. RS $4-40.0 \mathrm{mg} / \mathrm{kg}$, with $L$. RS4 + treacle -39.0 $\mathrm{mg} / \mathrm{kg}$, in control $-38.0 \mathrm{mg} / \mathrm{kg}$. 
Table 3. Composition of clover silage obtained under natural condition with and without introduction of Lactobacillus $\mathrm{RS} 4(\mathrm{~g} / \mathrm{kg}) *$

\begin{tabular}{|l|c|c|c|}
\hline \multirow{2}{*}{ Components } & \multicolumn{3}{c|}{ Silages } \\
\cline { 2 - 4 } & control & L. RS4 & L. RS4 + treacle \\
\hline Dry matter, g/kg & 400 & 388 & 402 \\
\hline Metabolic energy, MJ/kg (calculated) & 3.8 & 3.8 & 3.8 \\
\hline Crude protein, g/kg & 61.0 & 62.8 & 62.7 \\
\hline Crude fat, g/kg & 10.8 & 10.2 & 10.8 \\
\hline Crude fiber, g/kg & 106.1 & 102.4 & 107.2 \\
\hline Water soluble carbohydrates, g/kg & 12.0 & 12.6 & 17.4 \\
\hline Calcium, g/kg & 6.9 & 6.8 & 6.6 \\
\hline Phosphorus, g/kg & 1.3 & 1.2 & 1.3 \\
\hline Carotene $\mathrm{mg} / \mathrm{kg}$ & 38.0 & 40.0 & 39.0 \\
\hline
\end{tabular}

* Mean square deviation of triplicate data $\sigma \leq 12 \%$.

\subsection{Economic Efficiency}

The obtained facts testify the benefit of clover ensiling with application of $L$. RS4; this variant had $6.1 \%$ protein and $8.2 \%$ soluble sugars more than control sample. Economic expediency of clover preservation according to the proposed technology is confirmed by simple standard calculations. The data presented in Table 4 demonstrates the decrease in financial expenses required for herbs ensiling with introduced $L$. RS4, for one order, compared to variant with treacle.

Table 4. Economic efficiency of three variants of silage prepared from herbs with high-protein content

\begin{tabular}{|c|c|c|c|c|c|}
\hline \multirow[t]{2}{*}{ Variant } & \multirow{2}{*}{$\begin{array}{c}\text { Price, } \\
\mathrm{rub} / \mathrm{l}, \mathrm{rub} / \mathrm{kg}\end{array}$} & \multicolumn{2}{|c|}{ The dose of } & \multicolumn{2}{|c|}{ Expenses, rub } \\
\hline & & $1 \mathrm{t}$ & $15 \mathrm{t}$ & $1 \mathrm{t}$ & $15 \mathrm{t}$ \\
\hline L. RS4 & $160 *$ & 0.0661 & 11 & 10.67 & 160 \\
\hline treacle & $3.30 * *$ & $40 \mathrm{~kg}$ & $600 \mathrm{~kg}$ & 132 & 1980 \\
\hline L. RS4+ treacle & 163.30 & $0.0661+40 \mathrm{~kg}$ & $11+600 \mathrm{~kg}$ & 142.67 & 2140 \\
\hline
\end{tabular}

* Market price of «Universal silage ferment», JSC «TatSPU«BioAgro»;

** Market price of treacle, JSC «Sugar Plant», Buinsk, Tatarstan Republic.

\section{Conclusions}

Application of native strain of Lactobacillus RS4 at conservation of the dried leguminous species like red clover allowed us to receive the forage of high quality. Active development of these bacteria promoted considerable accumulation of lactic acid in plant mass and preservation of nutrients in forage. According to published results the microbial proteolysis of the green crops is limited, though lactic fermentation indirectly stimulated clover protein hydrolysis by endogenous proteases (Winters et al., 2000; Winters et al., 2001). Therefore, the introduced strain of $L$. RS4 gives an additional possibility for digestion of partially hydrolyzed proteins by its own proteases and increases the availability of silo proteins as well as the level 
of essential amino acids for feeding of animals. It is especially important that the expenses of proposed technology with introduction of Lactobacillus RS4 into plant biomass are very low and do not exceed 11 rubles (about 2 cents) for treatment of 1 ton of herbs.

\section{Acknowledgement}

This work was performed in frames of the Russian Government Program for Competitive Growth of Kazan Federal University.

\section{References}

Acosta Aragon, Y., Jatkauskas, J., \& Vrotniakiene, V. (2012). The Effect of a Silage Inoculant on Silage Quality, Aerobic Stability, and Meat Production on Farm Scale. ISRN Veterinary Science. http://dx.doi.org/10.5402/345927.

Cussen, R. F., Merry, R. J., Williams, A.P., \& Tweed, J. K. S. (1995). The effect of additives on the ensilage of forage of differing perennial ryegrass and white clover content. Grass and Forage Science, 50(3), 249-258. http://dx.doi.org/10.1111/j.1365-2494.1995.tb02320.x

Dellaglio, F., \& Torriani, S. (1986). DNA-DNA homology, physiological characteristics and distribution of lactic acid bacteria isolated from maize silage. Journal of Applied Bacteriology, 60(2), 83-92. http://dx.doi.org/10.1111/j.1365-2672.1986.tb03363.x

Driehuis, F., \& Oude Elferink, S. J. (2000). The impact of the quality of silage on animal health and food safety: a review. Veterinary Quarterly, 22(4), 212-216. http://dx.doi.org/10.1080/01652176.2000.9695061

Gibadullina, F. S. (2007). Reserves of increase protein nutritiousness of forages and rations for cattle at the present phase. Kazan: Fen. p. 187.

GOST 23637-90. Silage. Specifications.

Grigoriev, N. G., Volkov, N. P., \& Vorob’yov, E. S. (1989). Biological usefulness fodders. Moscow: Agropromizdat. p 287.

Kosolapov, V. M., Bondarev, V. A., \& Klimenkov, V. P. (2009). Preparation of High Quality Silage from Clover. Bullitin of Russian Academia of Agricalture Sciense, 4, 55-57.

Kvasnikov, E. I., \& Nesterenko, O. A. (1975). Lactic Acid Bacteria and Their Application. Moscow: Nauka. P. 384.

McDonald, P. (1985). Biochemistry of Silage. Moscow: Agropromizdat. p. 272.

Methods of General Bacteriology. Ed. by Gerhard, F. M. (1984). Moscow: Mir. (3) p. 95-264.

Nadezhkin, S. N., Kuznetsova, I. Y., \& Baimmiev, Kh. M. (2006). The Red Clover. Ufa: BashGAU. p 159

Oshima, M., \& McDonald, P. (1978). A review of the changes in nitrogenous compounds of herbage during ensilage, Journal of the Science of Food and Agriculture, 29(6), 497-505. http://dx.doi.org/10.1002/jsfa.2740290602 
Oshima, M., McDonald, P., \& Acamovic, T. (1979). Changes during ensilage in the nitrogenous compounds of fresh and additive treated ryegrass and Lucerne. Journal of the Science of Food and Agriculture, 30(2), 97-106. http://dx.doi.org/10.1002/jsfa.2740300202

Petukhova, E. A., Bessarabova, R. F., Khaleneva, L. D., \& Antonova, O. A. (1989). Zootechnical Analysis of Forages. Moscow: Agropromizdat. p. 253.

Shurkhno, R. A., Gareev, R. G., Abulkhanov, A.G., Validov, Sh. Z., Boronin, A. M., \& Naumova, R. P. (2005). Fermentation of High-Protein Plant Biomass by Introduction of Lactic Acid Bacteria. Journal Applied Biochemistry and Microbiology, 41(1), 79-89.

Shurkhno, R. A., Gareev, R. G., Shaitanov, O. L., Muginov, N. L., \& Naumova, R. P. (2001). Comparative Study of Environment-forming Activity of different grades of clover. Grassland, 2, 17-18.

Shurkhno, R. A., Validov, Sh. Z., Boronin, A. M., \& Naumova, R. P. (2006). Modeling of Lactic Acid Fermentation of Leguminous Plant Juices. Journal Applied Biochemistry and Microbiology, 42(2), 229-235.

Shurkhno, R. A., Validov, Sh. Z., Khadeev, T. G., Naumova, R. P., \& Ilinskaya, O. N. (2007). A method for diagnosing ensilaging of plants. RUS Patent 2309605.

Van de Guchte, M., Serror, P., Chervaux, C., Smokvina, T., Ehrlich, S. D., \& and Maguin, E. (2002). Strees resposes in acid bacteria. Antonie Van Leeuwenhoek International Journal of General and Molecular Microbiology, 82(1), 187-216. http://dx.doi.org/10.1023/A:1020631532202

Vyayzenen, G. N., Tokar, A. I., Lukin, Y. N., Levosko, M. Y., Vyayzenen, G. A., \& Vyayzenen, A. G. (2010). The Production of Forages taking into account the chemical composition. Grassland, 3, 33-37.

Watson, S. J., \& Nash, M. J. (1964). Preparation and using of hay and silage. Moscow: Kolos. p. 662.

Winters, A. N., Cockburn, J. E., Dhanoa, M. S., \& Merry, R. J. (2000). Effect of Lactic Acid Bacteria in Inoculants on Changes in Amino Acid Composition during Ensilage of sterile and Nonsterile Ryegrass. Journal Applied Microbiology, 89(3), 442-451. http://dx.doi.org/10.1046/j.1365-2672.2000.01133.x

Winters, A. N., Fychan, R., \& Jones, R. (2001). Effect of Formic Acid and a Bacterial Inoculant on the Amino Acid Composition of Grass Silage and on Animal Performance. Grass and Forage Science, 56(2), 181-192. http://dx.doi.org/10.1046/j.1365-2494.2001.00265.x

Woolford, M. K., \& Sawczyc, M. K. (1984). An investigation into the effect of cultures of lactic acid bacteria on fermentation in silage, Grass and Forage Science, 39(2), 149-158. http://dx.doi.org/10.1111/j.1365-2494.1984.tb01676.x

Zaripova, L. P., Gibadullina, F. S., Shakirov, Sh. K., Tagirov, M. Kh., Nurthginov, M. G., Khazipov, N. N., Bykova, M. Yu., Gabdrakhmanov, I. Kh., Shurkhno, R. A., \& Lukmanov, A. 
A. (2010). Fodders of the Republic Tatarstan: composition, nutritiousness and using. Kazan: Fen. p. 271.

Zherukov, B. Kh., Magomedov, K. G., Berbekova, N. V., \& Kardanova Z. M. (2003). Organic Nitrogen as a Protein Source. Bullitin of Russian Academia of Agricalture Sciense, 2, 51-52.

\section{Copyright Disclaimer}

Copyright for this article is retained by the author(s), with first publication rights granted to the journal.

This is an open-access article distributed under the terms and conditions of the Creative Commons Attribution license (http://creativecommons.org/licenses/by/3.0/). 